\title{
Manifest and Latent Relations between Intracranial Capacity and Cephalofacial Indexes
}

\author{
Relaciones Manifiestas y Latentes entre la Capacidad Intracraneal e Índices Cefalofaciales
}

\author{
${ }^{*, * *}$ Agron M. Rexhepi \& ***Behlul Brestovci
}

REXHEPI, A. M. \& BRESTOVCI, B. Manifest and latent relations between intracranial capacity and cephalofacial indexes. Int. J. Morphol., 30(3):786-790, 2012.

SUMMARY: The goals of this study were to find the average intracranial capacity of the living male-entities of Kosovo Albanian population, to define cephalofacial indexes and their interrelations with intracranial capacity and to explore their latent structure. Eight cephalofacial variables have been measured in 571 male entities of the Kosovo Albanian population, aged 18-35 years old. Of these measurements, 6 cephalofacial indexes and intracranial capacity were calculated. According to the results of Table it can be concluded that most of Albanian males from Kosovo have long, wide and average height head, as well as most of them have brachiocephalic head, low hypsicephalic, and tapeinocephalic head, with intracranial capacity 1379.2cc. Regression Analyzes show that among other cephalofacial indexes, vertical cephalic index and transversal cephalic index have higher predictive influence on size of the intracranial capacity (VCI=1.764; TCI=-1.45). The possibility of the prediction of Intracranial Capacity (ICC) based on the values of VCI and TCI argues their joint projection on the first extracted latent factor, which has been nominated as factor of the head volume. The latent structure of the cephalofacial indexes consists of three latent factors: 1) factor of the head volume; 2) facial factor; 3) cephalic factor.

KEY WORDS: Brachiocephalic; Regression analyzes; Factorial analyzes; Head volume.

\section{INTRODUCTION}

Cephalometry is a branch of anthropometry means measurements of the head of a living entity taken either directly (anthropometric measurements) or indirectly (radiography, MRI, CT, stereological method, ultrasonic cephalometry). The information collected from the cephalofacial measurements enables a chronological study of the anthropological status of today's nations and previous nations too (Coon, 1939; Dhima, 1985; Ylli, 1975). Also, cephalometry is widely used as diagnostic, treatment and research tool by many medical practitioners (neurologists, orthodontics, prosthodontists, maxillofacial and plastic surgeons, pediatric dentists, measurement of the fetal head), as well as anthropologists (anthropological researches). From the cephalofacial variables that can be measured using the cephalometry method, one can estimate intracranial capacity and cephalofacial indexes.

Generally, the intracranial capacity is considered to be a more accurate indicator of the brain volume than head size, respectively intracranial cavity as a space formed inside the skull indirectly may present the brain volume. However, according to Edland et al. (2002), and Jenkis et al. (2000) neuroimaging studies did not always support an association between intracranial capacity and cognition. The ratio between the brain volume and the cranial cavity volume has been found to be constant in adults 20-55 years old (Davis \& Wright, 1977). So, the cranial cavity may be used as an indirect approach to evaluate the size of the brain. This cavity forms eight fused cranial bones: the frontal, occipital, sphenoid, ethmoid, parietal and temporal bones (Martin et $a l ., 2001)$. Intracranial capacity is an important measurement in the different studies, such as: exploration of the racial differences, abnormalities of cranial size and shape, etc.

There are various methods for measurement of intracranial capacity: the linear anthropometric measurements, the packing/filling method, planimetry method, the point-counting method. But, until now craniologists have not found any method which, at the same time, has simple technique of execution, as well as precise

\footnotetext{
"Sport Center for increasing of morpho-functional abilities, Fitness \& Nutrition "Corpore Sano", 10000 Pristina, Kosovo.

*** University College for Sport Education "Eurosporti”, 10000 Prishtina, Kosovo.

****Faculty of Special Education and Rehabilitation, University of Zagreb, Zagreb, Croatia.
} 
measurement. According to Sahin et al. (2007), even if the estimation of the intracranial capacity (ICC) using the anthropometric method is easy, the results may deviate from the actual values. To minimize the errors on prediction of ICC, using anthropometric measurements, Sahin et al. (2007) proposes that the regression formulae must be readjusted based on different races and nations.

According to Turchin (1977) the values of capacity of the intracranial capacity, in adult modern men are between $1,200-1,700 \mathrm{~cm}^{3}$.

Index values are some type of count over several sampling units; meanwhile some biologists use them as relative abundance values.

The cephalic index was defined by Swedish anatomist Anders Retzius. This index was widely used in physical anthropology to classify ancient human remains found in Europe, as well as to categorize human populations.

The goals of this study were to find the average intracranial capacity of the living male-entities of Kosovo Albanian population, to define cephalofacial indexes and their interrelations with intracranial capacity and to explore their latent structure.

\section{MATERIAL AND METHOD}

The study was carried out at the Institute of Sports Anthropology in Pristine, Kosovo, and received approval from the local Ethics Committee.

While most of the available studies regarding the intracranial capacity and indexes of the head have been done on dry skulls (craniometry), only a few of them have been done on living subjects (cephalometry).

Eight cephalofacial measurements were done in 571 male entities of Kosovo Albanian population, during the period 1997-2005. The examined entities aged $18-40$ years, were chosen randomly, but always respecting the rule that their psycho-physic, dental and soft tissue condition were normal.

Following the definitions of Martin and Saler all measurements have been taken by an anthropological cephalometer, as well as with sliding compass, with accuracy of $1 \mathrm{~mm}$.

The following variables were measured:

- G-Op (glabela-opistocranium) - head length;
- Eu-Eu (eurion-eurion) - head width;

- V-Po (vertex-porion) - head height;

- N-Gn (nasion-gnathion) - face height;

- Zy-Zy (bizygomatic) - Maximal facial breadth;

- Go-Go (gonion-gonion) - bigonial mandibular breadth;

- N-Ns (nasion-nasospinale) - Nasal height;

- Al-Al (alare-alare) - nasal breadth;

From these measurements were calculated 6 cephalofacial indexes and intracranial capacity:

- HCI - Horizontal cephalic index shows the proportion of the maximum breadth of the head (eu-eu) to its maximum length (g-op);

- VCI - Vertical cephalic index shows the ratio of the maximum height of the head (v-po) to its maximum length (g-op);

- TCI - Transverse cephalic index shows the proportion of the maximum head height (v-po) to its maximum breadth (eu-eu);

- TFI - Total facial index shows the ratio of the morphological height of the face (n-gn) to its maximal width between the zygomatic prominences (zy-zy);

- FMI - Facial-mandibular index - shows the ratio of the morphological height of the face (n-gn) to the mandibular width (go-go).

- NI - Nasal index.- shows the ratio of the maximum breadth of the external nose (al-al) to its height from the nasal root to where the septum is confluent with the upper lip (n-ns).

Intracranial capacity has been calculated by using three measured principal dimensions of the head: head length, head width, and head height. Then, using the following formula derived by Lee-Pearson the cranial capacity has been computed:

$$
0.000337 \times(L-11) \times(\mathrm{W}-11) \times(\mathrm{H}-11)+406.01
$$

The statistical analysis was accomplished through the SPSS program version 17 . The gain data were analyzed through descriptive parameters, regression analyses, and factorial analyses.

\section{RESULTS AND DISCUSION}

The descriptive values of the measured variables are shown in Table I, whereas the descriptive values of the calculated variables (intracranial capacity, and cephalofacial indexes) are shown in Table II.

All measured variables, as well as cephalofacial 
REXHEPI, A. M. \& BRESTOVCI, B. Manifest and latent relations between intracranial capacity and cephalofacial indexes. Int. J. Morphol., 30(3):786-790, 2012.

Table I. Descriptive statistics - measured variables.

\begin{tabular}{lcccc}
\hline Variables & Minimum & Maximum & Mean & Std. Deviation \\
\hline G-Op & 168.00 & 209.00 & 188.7732 & 6.32114 \\
Eu-Eu & 116.00 & 191.00 & 157.6375 & 6.57667 \\
V-Po & 104.00 & 143.00 & 121.5989 & 6.95135 \\
N-Gn & 105.00 & 144.00 & 122.4746 & 6.45312 \\
Zy-Zy & 109.00 & 155.00 & 136.0166 & 8.14658 \\
Go-Go & 93.00 & 147.00 & 108.1252 & 5.86677 \\
N-Ns & 38.00 & 62.00 & 51.1007 & 3.40690 \\
Al-Al & 29.00 & 45.00 & 34.8581 & 2.68590 \\
\hline
\end{tabular}

Table II. Descriptive statistics - cephalofacial indexes.

\begin{tabular}{lcccc}
\hline Indexes & Minimum & Maximum & Mean & Std. Deviation \\
\hline ICC & 1019.80 & 1755.85 & 1379.1906 & 99.89482 \\
HCI & 61.70 & 100.53 & 83.5665 & 3.78697 \\
VCI & 52.74 & 76.00 & 64.4579 & 3.79980 \\
TCI & 63.64 & 95.49 & 77.2358 & 4.92157 \\
TFI & 74.31 & 115.60 & 90.3099 & 6.44727 \\
FMI & 83.67 & 139.78 & 113.5381 & 7.72276 \\
NI & 51.72 & 90.00 & 68.5073 & 6.87588 \\
\hline
\end{tabular}

indexes have given low values of the standard deviation this fact indicates that the data points are very close to the average values. Whereas, high value of the standard deviation of the measured variable - intracranial capacity, indicates that the data of this variable is spread out over a large range of the average values.

Based on the data of regressive analyses (Table III) it can be concluded that the system of six independent variables (NI, TCI, TFI, HCI, FMI, VCI) explains $18.9 \%$ of total variability of the dependant variable (intracranial capacity), as well as its significant prediction.
The results shown on Table III indicate that three cephalic indexes (Horizontal Cephalic Index - HCI, Vertical Cephalic Index - VCI, and Transversal Cephalic Index - TCI) have significantly predictive influence on Intracranial Capacity (ICC), compared with facial indexes.

Factor analysis is used to study the patterns of relationship among many manifest variables, with the goal of discovering latent variables which affect them, and could not be measured directly (Darlington RB). In other words, factor analysis is a statistical method used to describe variability among observed (manifest) and correlated varia-

Table III. Regressive analyzes. Predictors: (Constant), NI, TCI, TFI, HCI,

FMI, VCI. b. Dependent Variable: ICC (intracranial capacity).

\begin{tabular}{lccccc}
\hline Model & $\mathbf{R}$ & $\mathbf{R} 2$ & Adjusted $\mathbf{R}^{2}$ & $\mathbf{F}$ & Sig. \\
\hline $\mathbf{1}$ & $.445 \mathrm{a}$ & .198 & .189 & 23.166 & $.000 \mathrm{a}$ \\
\hline
\end{tabular}

Table IV. Beta Coefficients. a. Dependent Variable: ICC (intracranial capacity).

\begin{tabular}{lccc}
\hline Model & Beta Coefficients & $\mathbf{t}$ & Sig. \\
\hline HCI & -1.010 & -2.452 & .014 \\
VCI & 1.764 & 3.373 & .001 \\
TCI & -1.450 & -2.577 & .010 \\
TFI & .078 & 1.814 & .070 \\
FMI & .019 & .422 & .673 \\
NI & .105 & 2.626 & .009 \\
\hline
\end{tabular}

bles in terms of a potentially lower number of unobserved (latent) variables called factors.

In this study, according to principal component analysis of Factor Analysis, with rotation method direct oblimin, and using Gutman-Kaiser criteria of minimal common variability (always respecting the law of parsimony), have been extracted three latent components (factors) that explain $71.5 \%$ of total variance (Table V). 
Table V. Factor Analysis - Total Variance Explained. Extraction Method: Principal Component Analysis.

\begin{tabular}{lcccc}
\hline & Total & \% of Variance & Cumulative $\%$ & $\mathbf{H}^{2}$ \\
\hline ICC & $* 2.019$ & $* 28.839$ & $* 28.839$ & .482 \\
HCI & $* 1.636$ & $* 23.370$ & $* 52.209$ & .943 \\
VCI & $* 1.351$ & $* 19.303$ & $* 71.512$ & .889 \\
TCI & .901 & 12.876 & 84.388 & .972 \\
TFI & .607 & 8.678 & 93.066 & .579 \\
FMI & .484 & 6.907 & 99.974 & .715 \\
NI & .002 & .026 & 100.000 & .425 \\
\hline
\end{tabular}

Table VI. Pattern Matrix.

\begin{tabular}{lccc}
\hline Variables & Factor 1 & Factor 2 & Factor 3 \\
\hline ICC & $* .675$ & .025 & .180 \\
HCI & .242 & -.015 & $* .945$ \\
VCI & $* .942$ & -.018 & .008 \\
TCI & $* .696$ & -.008 & -.684 \\
TFI & -.231 & $* .719$ & .017 \\
FMI & .142 & $* .828$ & -.114 \\
NI & -.064 & $*-.647$ & -.065 \\
\hline
\end{tabular}

Table VII. Component Correlation Matrix.

\begin{tabular}{lccc}
\hline Factors & $\mathbf{1}$ & $\mathbf{2}$ & $\mathbf{3}$ \\
\hline $\mathbf{1}$ & 1.000 & -.023 & -.020 \\
$\mathbf{2}$ & -.023 & 1.000 & -.006 \\
$\mathbf{3}$ & -.020 & -.006 & 1.000 \\
\hline
\end{tabular}

Extraction Method: Principal Component Analysis Based on the data of Table VI it can be noticed that the best projections on the first extracted latent factor, which explain $28,8 \%$ of total variance, have realized variables (ICC, VCI, TCI) that inform about the head volume. So, this factor might be appointed as the factor of the head volume.

On the second extracted latent factor, which explains $23.4 \%$ of the total variance, the best projections have realized three facial variables. Rightly, this factor might be known as the facial factor.

On third latent factor that explains $19.3 \%$ of the total variance, the best projection has realized horizontal cephalic index (HCI). This factor might be named as the cephalic factor.

The results shown on Table VII, show that the three extracted latent factors have not realized significant correlation between them, so they can remain independent.

\section{CONCLUSIONS}

According to the results of Table I can be concluded that most of Albanian males from Kosovo have a long and wide head, as well average height. Also, according to the results of Table II can be concluded that most of them have brachiocephalic head, low hypsicephalic, and tapeinocephalic head (Rexhepi, 2008), as well with intracranial capacity $1379.2 \mathrm{cc}(\min =1020 \mathrm{cc} ; \max =1756$ cc). Multiple Linear Regression Analyzes shows that system of cephalofacial indexes, even if very poorly, significantly can predict the size of the intracranial capacity. Meanwhile, among other cephalofacial indexes, vertical cephalic index and transversal cephalic index have the higher predictive influence of the size of intracranial capacity ( $\mathrm{VCI}=1.764$; $\mathrm{TCI}=-1.45)$.

ACKNOWLEDGMENTS. Authors would like to express their gratitude to: Mr. Labinot Zogaj - certified court translator/interpreter for English language, for his contributions as lecturer of this manuscript.

REXHEPI, A. M. \& BRESTOVCI, B. Relaciones manifiestas y latentes entre la capacidad intracraneal e índices cefalofaciales. Int. J. Morphol., 30(3):786-790, 2012.

RESUMEN: Los objetivos de este estudio fueron conocer la capacidad intracraneal (CIC) media en hombres de población Albanesa de Kosovo, para definir los índices cefalofaciales y sus interrelaciones con la CIC, así como para explorar su estructura latente. Ocho variables cefalofaciales fueron medidas en 571 hombres de población Albanesa de Kosovo, con edades entre 18-35 años. A partir de estas mediciones se calcularon 6 índices cefalofaciales y CIC. De acuerdo con el primer objetivo, la mayoría de los hombres Albaneses de Kosovo tienen una cabeza larga, ancha y de altura media, así como la mayoría de ellos son braquiocefálicos, hipsicefálicos leves y de cabeza tapeinocefálica, con CIC de 1379,2cc. El análisis de regresión muestra que entre otros índices cefalofaciales, el índice cefálico vertical (ICV) e índice cefálico transversal (ICT) tienen la mayor influencia de predicción del tamaño de la capacidad intracraneal (ICV $=1,764$; ICT = -1,45). La posibilidad de la predicción del ICV e ICT sobre la CIC, argumentan su proyección (junto con CIC) sobre el primer factor latente extraído, el cual ha sido denominado factor del volumen de la cabeza. La estructura latente de los índices cefalofaciales está constituida por tres factores latentes: 1) el factor del volumen de la cabeza, 2) el factor facial y 3) el factor cefálico.

PALABRAS CLAVE: Braquiocefálico; Análisis de regresión; Análisis factorial; Volumen de la cabeza. 


\section{REFERENCES}

Coon, C. S. The races of Europe. $2^{\text {nd }}$ ed. New York, Macmillan, 1939. p. 293.

Darlington, R. B. Factor Analysis, 2011. Available in: http:// www.psych.cornell.edu/darlington/factor.htm

Davis, P. J. M. \& Wright, E. A. A new method for measuring cranial cavity volume and its application to the assessment of cerebral atrophy at autopsy. Neuropathol. Appl. Neurobiol., 3:341$58,1977$.

Dhima, D. H. A. Gjurmime antropologjike per shqiptaret. Tirana, 1985. pp.28-9, 106-12, 126-8.

Edland, S. D.; Xu, Y.; Plevak, M.; O’Brien, P.; Tangalos, E. G.; Petersen, R. C.\& Jack, Jr. C. R. Total intracranial volume: Normative values and lack of association with Alzheimer's disease. Neurology, 59(2):272-4, 2002.

Martin, R.; Ober, W.; Garrison, C.; Welch, K. \& Hutchings, R. T. Fundamentals of Anatomy and Physiology. $5^{\text {th }}$ ed. New Jersey, Prentice Hall, 2001. p.195.

Sahin, B.; Acer, N.; Sonmez, O. F.; Emirzeoglu, M.; Basaloglu, H.; Uzun, A. \& Bilgic, S. Comparison of Four Methods For Estimation of Intracranial Volume: A Gold Standard Study. Clin. Anat., 20(7):766-76, 2007.

Rexhepi, A. \& Meka, V. Cephalofacial morphological characteristics of Albanian Kosova population. Int. J. Morphol., 26(4):935-40, 2008.

Turchin, V. F. The Phenomenon of Science. Chapter V. New York, Columbia University Press, 1977.

Ylli, A. Disa të dhëna kraniometrike. (in Albanian) Tirana, 1975. pp.64-97.
Correspondence to:

Agron Rexhepi

University College for Sport Education "Eurosporti"

Str. " Sali Butka" Nr. 31/D, 10020 Pristina

KOSOVA

Phone: +377 44110855 ; +38649500 012

Email: agronmrexhepi@gmail.com

Received: 23-05-2011

Accepted: 01-03-2012 